of the Lord. This statement was a surprise to me and an opinion on that I though a boy in My seventeenth year I think it was the following Sunday Mr. Carlson, father, and I were baptized and a number besides. I think ten or twelve altogether. David Powell whom was an elder officiated. It was not until several days after the meeting above referred to that I learned that something more than common transpired. But it was then told that the gift of tongues had been enjoyed which I was now prepared to believe by the silent testimony to me that the work was of the Lord. It left an impression upon me that will never be obliterated while my memory shall last.

\title{
LUMBERMEN AT CLINTON: NINETEENTH CENTURY SAWMILL CENTER
}

\author{
by George Wesley Sieber \\ Wisconsin State University-Oshkosh
}

Professor Sieber ${ }^{\circ}$ was born in Evansville, Indiana in 1930 but has made Wisconsin his home since 1943. He received his Ph.D. in history from the University of Iowa in 1960 and has. been teaching at Wisconsin State University since 1962. Professor Sieber is presently engaged in writing a book length manuscript: "Sawmilling on the Mississippi: An Iowa Firm in the Nineteenth Century," which will be submitted to Iowa University Press. The following article is based primarily on the W. J. Young Lumber Company papers located at the University of Iowa.

This article depicts the role of Clinton, Iowa in nineteenth century lumber production, the companies, the men who ran them, and their socio-economic role as employers. Attention is focused on the labor force and wages. Emphasis is on W. J. Young \& Company whose records constitute the main source of the study.

'Professor Sieber has been the author of two other articles which have appeared in the ANNALS: "Sawlogs for a Clinton Sawmill," Vol. 37, No. 5, (Summer, 1964) and "Railroads and Lumber Marketing 1858-78: The Relationship Between an Iowa Sawmill Firm and the Chicago \& Northwestern Railroad," Vol. 39, No. 1, (Summer, 1967). 
In 1860 lumber ranked third, and in 1870, second in terms of capital investment in United States manufacturing industries. In both years lumber was third among American manufacturing industries in terms of product value. ${ }^{1}$ Before 1909, the only economic activities in Iowa that were generally more important than lumber, based on the value of the product, were those connected with agriculture. ${ }^{2}$ At times, as in 1889, the product of sawmills held first place in the Iowa economy. ${ }^{3}$ I

In 1869 Iowa ranked ninth among states in lumber production. ${ }^{4}$ That year Clinton produced more than 60 million feet of lumber, 24 million shingles, and 14 million lath. ${ }^{5}$ No city on the Mississippi south of St. Paul produced more. ${ }^{6}$ Clinton contained five sawmill companies in 1869. Table I shows that W. J. Young \& Company excelled in production, sales, and shipping. The Lamb family held controlling interests in two

TABLE 1

Production, Sales, and Shipments of Clinton Mills in 1869*

Company Production

W. J. Young \& Co.

C. Lamb \& Son Lamb, Byng \& Co.

Clinton Lumber $\mathrm{Co}$. Totals

\section{Company Sales}

W. J. Young \& Co.

C. Lamb \& Son Lamb, Byng \& Co.

Clinton Lumber Co. Totals

Number of Railroad Cars Loaded and Shipped in 1869

Feet of Lumber
$29,120,958$
$18,463,122$
$5,931,649$
$6,650,000$
$60,165,729$

Feet of Lumber

$25,539,256$

$18,928,909$

$3,675,595$

$5,500,000$

$53,643,759$

Shingles
$12,046,900$
$7,263,750$
$1,884,750$
$3,200,000$
$24,394,600$

\section{Shingles}

$10,889,500$

$8,150,000$

$1,822,000$

$2,500,000$

$23,361,500$

\section{Lath}

$6,714,796$

$4,612,530$

$1,698,200$

$1,550,000$

$14,575,526$

Lath

$4,931,800$

$4,385,100$

$1,029,500$

$1,200,000$

$11,546,400$
W. J. Young \& Co.
C. Lamb \& Son
3,798
2,522
Lamb, Byng \& Co.
Wheeler \& Warner
500
311
Totals
7,675

${ }^{\circ}$ Clinton Age, Feb. 11, 1870.

of the firms, but their combined output and sales lagged behind W. J. Young, whose aggregate sales amounted to $\$ 541$,332.84. C. Lamb \& Son was second with $\$ 403,000$. The cost of logs, labor, and general expenses to W. J. Young \& Company was $\$ 461,627.41 .^{7}$ This amount subtracted from sales left $\$ 79$, 705.43 for Young to account for in terms of proprietary interest. 
In 1870 Clinton manufactured approximately 72 to 80 million feet of lumber. This exceeded every other lumber center on the Mississippi except Minneapolis, which produced 120 million feet. ${ }^{8}$ At Lyons, adjoining Clinton to the north, David Joyce and other millmen produced about 12 million feet. As Table 2 illustrates, newspaper accounts occasionally lumped the output of Clinton and Lyons together for statistical purposes, and sometimes included their neighbor across the river -Fulton, Illinois. ${ }^{9}$

Newspaper editors may have exaggerated the prominence of their respective cities. Some of the newspaper figures exceed those of Young's records, but the latter also contain contradictions. Possibly they result from estimating production upon request of various journals before the end of the year.

Except for lath, W. J. Young \& Company production in 1869 exceeded that of any other two Clinton firms combined. Young did not, however, hold an undisputed lead down through the years. In 1876, for example, the combined figures

TABLE 2

\begin{tabular}{lccc}
$\begin{array}{r}\text { Examples of Statistics of Production for Clinton } \\
\text { Year }\end{array}$ & $\begin{array}{c}\text { Mills } \\
\text { Feet of Lumber }\end{array}$ & $\begin{array}{c}\text { Alone } \\
\text { Shingles }\end{array}$ \\
1868 & $59,543,838$ & & Lath \\
1869 & $60,165,729$ & $24,395,300$ & $14,575,526$ \\
1870 & $72,519,096$ & $28,409,400$ & $18,354,250$ \\
1873 & $72,301,066$ & $36,707,500$ & $16,224,900$ \\
1874 & $72,000,000$ & $37,000,000$ & $16,000,000$ \\
1875 & $95,000,000$ & $55,000,000$ & $45,000,000$ \\
1876 & $97,303,000$ & $29,340,000$ & $14,630,000$ \\
1882 & $166,387,963$ & $53,531,500$ & $14,435,000$ \\
1893 & $176,193,588$ & $43,585,250$ & $23,728,400$ \\
\multicolumn{5}{r}{ Examples } & of Statistics of Production for Clinton and Lyons \\
Year & Feet of Lumber & Shingles & Lath \\
1873 & $88,301,066$ & $41,707,500$ & $20,724,900$ \\
1882 & $227,212,963$ & $67,786,500$ & $39,119,000$ \\
\multicolumn{5}{c}{ Examples } & of Statistics of Production: Clinton, Lyons, Fulton \\
Year & Feet of Lumber & Shingles & Lath \\
1875 & $125,000,000$ & $70,000,000$ & $60,000,000$
\end{tabular}

${ }^{\circ}$ Clinton Age, Apr. 28, 1893 (Quotes from earlier years);

Feb. 11, 1870; Jan. 27, 1871; Jan. 7, 1874; Mar. 19, 1875;

Dec. 24, 1875; and Jan. 12, 1877. W. J. Young \& Co. memorandum, Dec. 29, 1882, Letter Press Book 85, 530-32.

for the two firms controlled by the Lamb family amounted to more than Young's production. ${ }^{10}$ 
For some years between 1870 and 1890, Clinton produced more lumber than any other city on the Mississippi River except Minneapolis. ${ }^{11}$ In 1875 and 1876 Clinton and Lyons produced 40.5 per cent of the total lumber cut in Iowa. Davenport was next with 17.2 , followed by Muscatine with 11.1 per cent. $^{12}$ In 1889, Iowa's lumber production was 571,166,000 board feet, valued at $\$ 12,056,000 .^{13}$ Iowa ranked ninth in the nation for lumber in 1869, tenth in 1879, and twelfth in 1889, but was no longer among the leading states in $1899 .{ }^{14}$

\section{II}

Concurrent with the growth of the sawmill firms, there arose cabinet shops, planing mills, and box factories-typical auxiliary industries in the Iowa lumber centers. ${ }^{15}$ Furniture manufacturing developed at Clinton, Dubuque, Davenport, and Burlington. ${ }^{16}$ Most notable at Clinton was Curtis Brothers \& Company, manufacturers of sash, doors, blinds, mouldings, stairwork, and other wood finishings. Charles F. Curtis, one of the founders of the firm in 1866, was from New York, and had lived in Illinois before coming to Clinton. ${ }^{17}$

By 1870 Clinton possessed wagon factories, a match factory, and a paper mill. ${ }^{18}$ In 1871 Chancy Lamb gave Clinton mechanics more work in the winter by building the first of several steam boats made locally for log towing. ${ }^{10}$ The sawmill firms also furnished business for engine and boiler factories at Clinton. By February, 1870, for example, the Clinton Union Works had built several engines for the Clinton Lumber Company, was at work on eight boilers for C. Lamb \& Son, and was doing repairs for W. J. Young \& Company and for the mill of Culbertson \& Smith across the river at Fulton. ${ }^{20}$

In 1877 the Clinton Iron Works advertised that they manufactured the Noyes Double and Singular Circular Saw Mill; Nichols' Gang Edgers; and Gang Saw Mills with Parsons' Improved Fender Posts and Guides. ${ }^{21}$ The Clinton mills were sites of numerous sawmill innovations and technological developments. For example, Hotchkiss credits Chancy Lamb as being the first millman to adopt the band saw for regular use on white pine timber. ${ }^{22}$ With so much local interest in sawmill machinery, some manufacturing of mill equipment was a natural development for Clinton businessmen. In the case of 
the Clinton Union Works, proprietor A. P. Hosford was also the president of the Clinton Lumber Company in 1872, and was interested in developing better power systems for gang saws. ${ }^{23}$

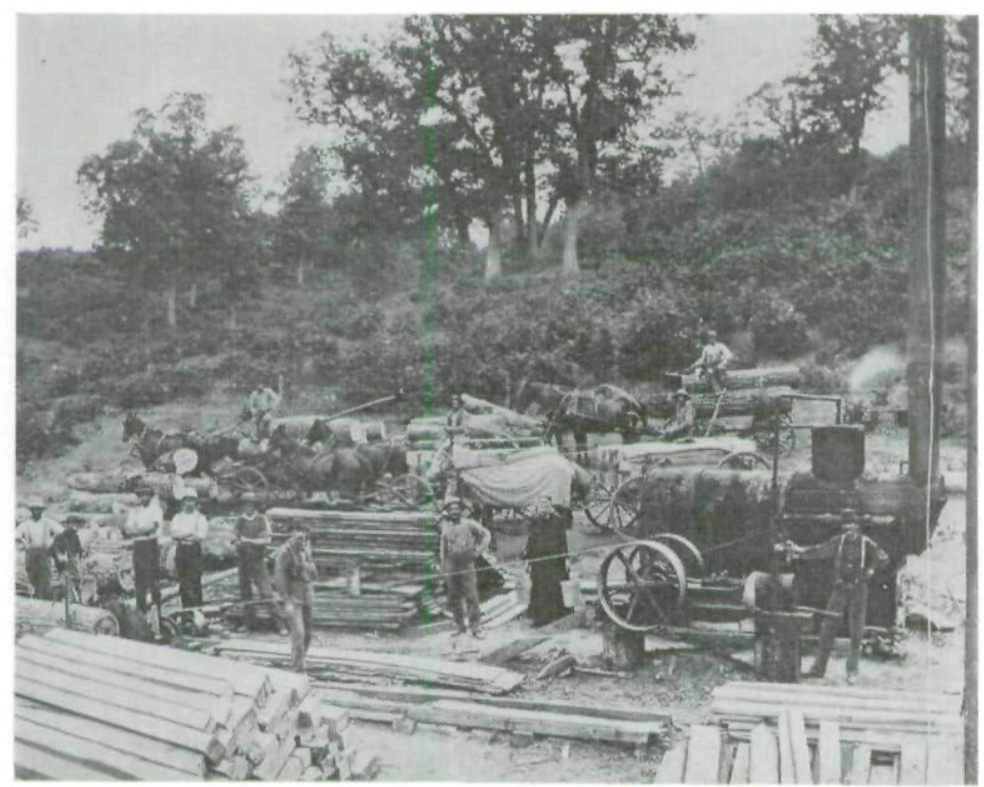

A typical sawmill of the late 1800's. Albert Oeschgar ran this mill near Monticello, lowa in 1895.

Some interesting relationships existed among the Clinton and Lyons lumbermen. The Lambs and the Gardiners had known each other in the East, and had pioneered together on the Illinois prairie. One of the Gardiners had owned an interest in Lamb, Byng \& Company, and later bought most of L. B. Wadleigh's interest in the firm of Wadleigh, Welles \& Company at Lyons. This firm became Gardiner, Batchelder \& Welles. L. B. Wadleigh had worked for W. J. Young \& Company as a young man, and later became president of the Clinton Lumber Company. Besides his other mills, Chancy Lamb at times held at least $\$ 10,000$ worth of stock in the Clinton Lumber Company. ${ }^{24}$ This is not to imply that the various 
firms had much interlocking ownership. On the whole they were clearly competitors. At times, however, when the firms changed ownership, no outside capitalists entered the field; the local proprietors merely made adjustments among themselves.

W. J. Young and Chancy Lamb were occasionally on good terms and at other times at odds with each other. In 1893, when both men were millionaires and near the end of their careers, Chancy Lamb reminisced about the early days when he had lost his mill by fire, and had succeeded in rebuilding all but the smokestack, which a hard-hearted and skeptical builder would not let him have until he had paid $\$ 150$. Lamb had gone to Young, whom he already owed $\$ 1,000$, and borrowed an additional $\$ 150$. Young confirmed this story. ${ }^{25}$

Conversely, early in 1867, Young explained to a customer that Lamb had done him a "serious injury" (not disclosed), and that they were not ready to have any dealings-just yet. Therefore Young could not buy the necessary items from Lamb to complete an order, as was customary among lumbermen, but suggested that the customer himself turn the order over to Lamb. The situation was a matter of principle, Young said, but he did not hesitate to recommend his competitor rather than disappoint the customer. ${ }^{26}$ Possibly Young's temperament throws light on this incident. A writer for the Northwestern Lumberman maintained that Young, in his younger days, possessed a "temper frequently his only master, and a source of trouble and subsequent humiliation. .." ${ }^{27}$ Again, in Timber and Men, the authors state that Young once became so angry that he nearly killed one of his sons whom he sent flying down a stairway; and Chancy Lamb is described as an individualist who was not about to have others tell him how to conduct his business. ${ }^{28}$

\section{IV}

How important were the sawmill men to the city of Clinton? The sawmills were the main stay of the city and supported two thirds of the population. Praise was common, as this newspaper item of 1871 demonstrates:

As usual we see our generous hearted mill owners are up to their usual style of doing things. The city wants a stable for its engine horses, and while the Fathers are hesitating as to 
the cost, along comes Messrs. Young, Lamb and Hosford, and propose to donate the lumber for the city. This is generous and is in keeping with all their acts. ${ }^{29}$

Of course the editor had no reason to raise the question as to who most feared fire in Clinton. The Clinton lumbermen were also vigorous in their efforts to secure an adequate city water works. They expected to gain better facilities to fight fire, and lower insurance rates on their mills and stocks of lumber. Young, Lamb, and others organized a company to obtain a water works in $1874 .^{30}$ In the same vein, lumbermen Lamb, Young, and A. P. Hosford each put up the largest sums of money in 1870 to launch the Iowa Midland Railway Company and build a road in a northwesterly course from Clinton. A local editor then commented, "The very interests which have subscribed the heaviest towards this enterprise can prosper without this road." ${ }^{31}$

After W. J. Young's death in 1896, a writer in the Northwestern Lumberman stated that the millman had not been indifferent to the municipal affairs of Clinton, and in one instance, "where a certain local newspaper had successfully championed a lively bill of some sort between contending factions to his liking," Young had mailed the publisher a check for "a good round sum as a form of requital best calculated to encourage what he thought the valuable policy of the paper." ${ }^{32}$ The citizens of Clinton elected Young mayor without opposition in 1864, and he used his logging contacts to obtain a tall flag pole for the city.

In 1871 Young was a member of the Citizens Association of Clinton, an organization to promote the manufacturing, mercantile, commercial, and industrial interests. ${ }^{33}$ In 1875 Young was President of the Clinton Savings Bank, and Chancy Lamb was Vice President. In 1877 Young and Lamb were directors of the Clinton National Bank, and Young's attorney, George B. Young (no relation) was Vice President of this institution, and later of W. J. Young \& Company. George B. Young was also active in other Clinton banks, as were other members of the city's lumber firms. In 1893 the directors of the City National Bank included Chancy Lamb, his sons Artemus and Lafayette; L. B. Wadleigh, and two of the Curtis brothers. At this time, W. J. Young, his oldest son, and Chancy Lamb, his 
two boys, and Young's attorney were all directors of the Clinton National Bank. All three Lambs were directors of the Merchants National Bank; and Artemus Lamb, L. B. Wadleigh, and George M. Curtis were directors of the Merchant and Manufacturers Insurance Company. ${ }^{34}$ In 1894 W. J. Young was President of the Clinton Savings Bank, and his eldest son Vice President of the Clinton National Bank. ${ }^{35}$

Young was President of the Clinton Gas Light and Coke Company in 1877, and Chancy Lamb Vice President. They held the same positions in 1893, and Artemus Lamb was the treasurer, while his younger brother Lafayette, and W. J. Young, Jr. were directors. George B. Young, now Vice President of W. J. Young \& Company, was also the attorney and a director of the gas company. ${ }^{36}$ We may conclude that the lumbermen were the business elite of the city.

The sawmill owners paid the highest property taxes among the citizens of Clinton. In 1877 Young paid \$6,271.91. ${ }^{37}$ The townfolk knew, of course, when millmen were wealthy; and some of them informed Young in 1892 that he was the chairman of a committee to investigate the expediency and probable cost of a new hospital building. ${ }^{38}$ Young gave money to numerous religious and charitable causes without ceremony. His more obvious philanthropic projects included the Esther Young Methodist Episcopal Church in Clinton, complete with nine chimes; and a building for the Young Men's Christian Association. ${ }^{39}$

\section{V}

The people of Clinton were aware that the lumbermen were active in organizing public utilities, banking, and other businesses, and that they engaged in philanthropy, but the major relationship of the millmen to the local citizens was that of employers to employees. The sawmills furnished more employment in Clinton than any other industry.

Clinton's population in 1870 was 6,129 people ${ }^{40}$ and approximately 800 men worked in the mills. ${ }^{41}$ In August (midsawing season), W. J. Young \& Company employed 389 men, nearly half of the total figure. ${ }^{42}$ The Iowa census of 1875 listed the male population of Clinton at $3,413 .{ }^{43}$ In 1876 the Clinton mills employed approximately 1,000 men, ${ }^{44}$ and 406 of 
them worked for Young. ${ }^{45}$ In 1880 the total population of Clinton was 9,052, and Young employed 556 men. The next year production soared, and Young's working force numbered $1,041{ }^{46}$

Clinton's population in 1890 was 13,619 , and Young used 1,226 men in August, the largest force ever for that month. ${ }^{47}$ In 1895 the population of Clinton was 17,375, including 8,615 men, but W. J. Young \& Company, no longer dynamic, employed not more than $83 .{ }^{48}$ Table 3 shows the number of workers who received wages from W. J. Young \& Company in August between 1864 and 1901. The "Lower Mill" operated during 1867-1893. The "Upper Mill" statistics include the office workers for every year, and few "clean-up" men from the "Lower Mill" after 1893.49

After the late 1840 's, many lumber workers in the lake states of Michigan, Minnesota, and Wisconsin were German, Irish, and Scandinavian immigrants. ${ }^{50}$ This was also true of the Iowa sawmill operatives. However, census reports indicate that by 1870 and 1880 more of the state's sawmill operatives had been born in the United States than in all other countries taken together (Table 4). Germany ranked first, and Ireland second among the mother countries of the foreign born operatives. Again, as regards the origins of the citizens living in Clinton County in 1880, for example, and in the city of Clinton in 1885, census reports show that the native born outnumbered the foreign, and more immigrants were from Germany and Ireland than from other individual countries. ${ }^{51}$

TABLE 3

$\begin{array}{lrrr}\begin{array}{c}\text { Number of Workers Receiving Wages in August } \\ \text { Year }\end{array} & \begin{array}{c}\text { 1863-1901 * } \\ \text { Upper Mill }\end{array} & \begin{array}{r}\text { Lower Mill } \\ \text { Total }\end{array} \\ 1863 & 32 & \ldots & 32 \\ 1864 & 38 & \ldots & 38 \\ 1865 & 107 & \ldots & 107 \\ 1866 & 106 & \ldots & 106 \\ 1867 & 97 & 91 & 188 \\ 1868 & 81 & 212 & 293 \\ 1869 & 86 & 260 & 346 \\ 1870 & 110 & 279 & 389 \\ 1871 & 87 & 147 & 234 \\ 1872 & 94 & 238 & 232 \\ 1873 & 109 & 251 & 360 \\ 1874 & 94 & 255 & 349 \\ 1875 & 93 & 285 & 378\end{array}$




$\begin{array}{rrrr}1876 & 95 & 311 & 406 \\ 1877 & 100 & 234 & 334 \\ 1878 & 104 & 218 & 322 \\ 1879 & 147 & 298 & 445 \\ 1880 & 74 & 482 & 556 \\ 1881 & 591 & 450 & 1,041 \\ 1882 & 322 & 468 & 790 \\ 1883 & 357 & 415 & 772 \\ 1884 & 340 & 406 & 746 \\ 1885 & 322 & 420 & 742 \\ 1886 & 319 & 412 & 731 \\ 1887 & 383 & 451 & 834 \\ 1888 & 410 & 380 & 790 \\ 1889 & 356 & 611 & 967 \\ 1890 & 442 & 784 & 1,226 \\ 1891 & 389 & 621 & 1,010 \\ 1892 & 392 & 720 & 112 \\ 1893 & 324 & 568 & 892 \\ 1894 & 320 & \ldots & 320 \\ 1895 & 83 & \ldots & 83 \\ 1896 & 67 & \ldots & 67 \\ 1897 & 265 & \ldots & 265 \\ 1898 & 59 & \ldots & 59 \\ 1899 & 23 & \ldots & 23 \\ 1900 & 12 & \ldots & 12 \\ 1901 & 8 & \ldots & 8\end{array}$

${ }^{\circ}$ Compiled from pay roll records. The 1863 figure is for September, the first month in the earliest ledger extant.

TABLE 4

Nativity of lowa Sawmill Operatives in 1870 and 1880 *

\begin{tabular}{lrlr} 
Place (1870 operatives) & No. & Place (1880 operatives) & No. \\
United States & 948 & United States & 1,581 \\
Germany & 205 & Germany & 419 \\
Ireland & 59 & Ireland & 185 \\
Sweden, Norway, Denmark & 47 & Norway and Sweden & 139 \\
England and Wales & 26 & British America & 57 \\
British America & 25 & Great Britain & 52 \\
Scotland & 8 & Other Countries & 48 \\
Southern Europe & 8 & & \\
France & 4 & & \\
Other Northern Europe & 2 & & \\
Italy & 0 & & \\
China and Japan & 0 & & \\
\multicolumn{1}{r}{ Total } & 1,332 & Total & \\
& &
\end{tabular}

${ }^{\circ} \mathrm{U}$. S. Department of Interior, The Statistics of the Population of the United States, June 1, 1870, Ninth Census, Vol. 1 (Washington: Government Printing Office, 1872), 733, and U. S. Department of Interior, The Statistics of the Population of the United States at the Tenth Census, June 1, 1880 (Washington: Government Printing Office, 1883), 507, 822.

One observer from Davenport indicated that most of the sawmill workers in the second half of the nineteenth century 
were German immigrants; another witness from Burlington stated that the workers were largely German, Irish, and Swedish. The latter description best fits the pay roll lists of W. J. Young \& Company. ${ }^{52}$

The lumber industry suffered labor shortages during wartime and peak periods of prosperity when other industries, or the army, needed men. ${ }^{53}$ During the Civil War, Young explained the delay in filling an order: "My men that I expected this morning I find have gone to the harvest fields. . ." ${ }^{54}$ The harvest was a lure to lumber workers nearly every year, wartime or not. ${ }^{55}$ In July, 1868 Young wrote: "We are short handed in mills. Men gone harvesting. Could not pay the price to keep them." ${ }^{56}$ But the situation was worse during war. In 1863 Young helped load railroad cars because he lacked workers, and commented: ". . . these war times Men Must work who never worked before, and those who always work Must work a little more." ${ }^{n 7}$

\section{VI}

Examination of the company's pay roll ledgers indicates that there was much mobility among sawmill employees. During the years 1863 through 1876, for example, the portion of the entire labor force of any one year that stayed the following year did not exceed 63 per cent. During the Civil War, only 31 per cent of the 1863 workers appeared in 1864, and the same percentage of 1864 employees in 1865. During those years the working force was much smaller than in the 1870's when there occurred a reduction in the proportion of turnover.

Following the panic of 1873, Young's total sales dropped five percent in $1874,{ }^{58}$ and he reduced the working force three percent. Thereafter, however, he increased the force until 1877. During the 1870 's, the proportion of each year's force that remained the following year steadily increased until 63 percent of the 1875 workers came back in 1876 . The next year, 1877, total sales fell off 11 percent. ${ }^{59}$ Young curtailed production and reduced the entire force by 72 workers, or 18 percent. Even so, 55 percent of the 1876 force was still at work.

A study of the company's labor turnover in the 1860's reveals that the majority of workers who stayed two years 
tended to be on hand during most of the following decade. In some instances workers left for a time and then returned. Young employed 892 workers in August, 1893, and claimed that 200 of them had been with him from five to 33 years. ${ }^{60}$ Of the small working band of 32 men in 1863, a hard core of four workers remained three decades later in 1894. Of the larger 1865 and 1867 working forces, eight percent of both groups (or nine and 15 workers respectively) remained in 1894.

\section{VII}

Table 5 depicts the total monthly sawmill pay roll of W. J. Young \& Company during August (mid sawing season) for the years 1863-1901. The separate figures for the two mills enable us to see their respective pay rolls, and the lack of any statistics for the Lower Mill after 1893 portrays a rather dramatic image of its demise.

For the years between 1876 (in some cases 1874) and 1892, the company papers contain "time tickets" or slips of paper that the time keeper signed, each stating an employe's position and wage per day, which enabled the compilation of the statistics in Table 6. The following discussion of wages is derived from the figures in Table 6, statistics and company correspondence. In 1860 Young turned down an offer of pork in exchange for lumber, commenting that he paid his hands cash every Saturday night. ${ }^{61}$ Millwrights made $\$ 1.50$ to $\$ 3$ per day. First class machinists earned $\$ 1.65$, common carpenters $\$ 1.25$, and laborers $\$ 1 .^{62}$ Young sought a man who could sort and pile lumber, a man capable of taking charge of the yard: "A good willing dutchman that understands the English language, I would prefer. . . . One that is not afraid to work himself. . ." for $\$ 1.25$ to $\$ 1.50$ per day. ${ }^{63}$

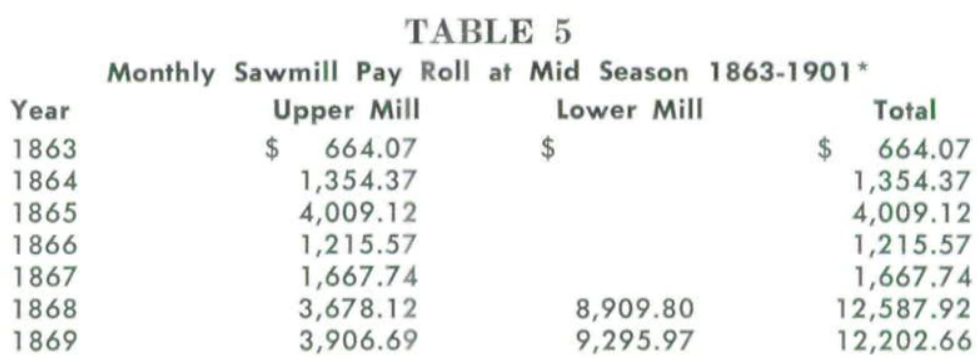




$\begin{array}{lrr}1870 & 4,509.13 & 10,332.53 \\ 1871 & 4,005.60 & 5,866.36 \\ 1872 & 3,866.87 & 8,189.76 \\ 1873 & 4,696.68 & 9,020.19 \\ 1874 & 4,034.64 & 9,611.64 \\ 1875 & 3,901.08 & 10,819.87 \\ 1876 & 3,779.14 & 10,476.69 \\ 1877 & 3,399.97 & 7,513.09 \\ 1878 & 3,420.44 & 6,746.52 \\ 1879 & 3,867.89 & 9,317.96 \\ 1880 & 3,014.64 & 13,177.08 \\ 1881 & 14,461.58 & 13,949.41 \\ 1882 & 14,052.97 & 18,508.21 \\ 1883 & 15,622.11 & 17,258.13 \\ 1884 & 13,562.96 & 14,904.12 \\ 1885 & 14,450.08 & 14,297.71 \\ 1886 & 11,769.87 & 14,116.87 \\ 1887 & 14,313.83 & 14,164.43 \\ 1888 & 16,164.93 & 13,947.01 \\ 1889 & 12,759.68 & 20,536.57 \\ 1890 & 12,246.69 & 20,195.14 \\ 1891 & 11,037.41 & 18,289.68 \\ 1892 & 13,273.11 & 22,386.30 \\ 1893 & 9,056.79 & 11,128.62 \\ 1894 & 11,812.69 & \\ 1895 & 2,861.37 & \\ 1896 & 1,929.28 & \\ 1897 & 8,141.41 & \\ 1898 & 2,429.36 & \\ 1899 & 982.09 & \\ 1900 & 547.10 & \\ 1901 & 435.47 & \\ 1 & 159 & \end{array}$

$14,841.66$

$9,871.96$

$12,057.63$

$13,716.87$

$13,645.28$

$14,720.95$

$14,255.83$

$10,913.06$

$10,166.96$

$13,393.89$

$16,191.72$

$28,410.99$

$32,561.18$

$32,880.24$

$28,467.08$

$28,747.79$

$25,886.74$

$28,478.31$

$30,111.94$

$33,296.25$

$32,441.83$

$29,327.09$

$35,659.41$

$20,185.41$

$11,812.69$

$2,861.37$

$1,929.28$

$8,141.41$

$2,429.36$

982.09

547.10

435.47

${ }^{\circ}$ Pay Roll Records, 1863-1901. All figures are for August except that of 1863 which is for September. The Upper Mill statistics for 1867 include wages of Lower Mill employees.

TABLE 6

Wages Per Day for Sawmill Jobs during August and September 1874-1892*

\begin{tabular}{lllll} 
Year & Carpenter & \multicolumn{1}{c}{ Mason } & Saw Filer & $\begin{array}{c}\text { Machinist } \\
1874\end{array}$ \\
18 & $\$ 3.00$ & $\$$ & $\$ 3.00$ \\
1876 & $1.50-2.50$ & & $1.50-2.50$ & \\
1877 & & & $1.40-1.60$ & \\
1879 & $1.00-1.50$ & 2.00 & 1.25 & \\
1881 & 2.00 & 3.00 & 1.50 & 2.75 \\
1882 & 2.65 & & & \\
1883 & & 3.50 & 1.50 & \\
1884 & & 3.50 & $1.50-2.00$ & \\
1886 & 1.75 & & & \\
1887 & 1.75 & 3.50 & & \\
1888 & $1.75-2.25$ & $3.00-3.50$ & 1.40 & $2.00-2.50$ \\
1889 & & 3.00 & & 2.50
\end{tabular}




\begin{tabular}{|c|c|c|c|c|}
\hline $\begin{array}{l}1890 \\
1891\end{array}$ & 1.25 & 3.50 & $1.50-3.35$ & \\
\hline Year & Edger & Loads Edger & Slab Saw & Slab Help \\
\hline 1876 & $\$ 2.00-2.25$ & $\$$ & $\$ 1.50$ & $\$$ \\
\hline 1877 & 1.75 & 1.40 & $1.30-1.50$ & \\
\hline 1879 & & & $1.25-1.30$ & \\
\hline 1881 & $1.50-1.70$ & 1.70 & $1.40-1.50$ & $1.40-1.45$ \\
\hline 1882 & & & $1.55-1.60$ & \\
\hline 1883 & & $1.55-1.70$ & 1.70 & 1.55 \\
\hline 1884 & & 1.65 & 1.55 & 1.45 \\
\hline 1886 & 2.25 & 1.40 & & \\
\hline 1887 & & & & 1.40 \\
\hline 1888 & 2.15 & 1.60 & & 1.40 \\
\hline 1889 & 2.15 & $1.40-1.60$ & & 1.30 \\
\hline 1890 & & 1.40 & 1.40 & $1.00-1.40$ \\
\hline 1891 & 2.15 & 1.40 & 1.40 & 1.40 \\
\hline 1892 & & & & $1.25-1.40$ \\
\hline
\end{tabular}
Island:

In 1861 Young wrote to a firm that repaired saws in Rock

Can you send me a No. 1 circular sawyer, one that can run the large rotary you have repaired for me. . . I I wish some good sober man that is industrious and will try to do the best he can for his employer. Will pay such a man $\$ 2.00$ per day. . . ${ }^{64}$

Young offered $\$ 2.50$ to $\$ 3$ per day to good muley and circular sawyers in $1865 .{ }^{65}$ In 1868 he offered to pay a gang sawyer $\$ 2.50$, commenting that houses were scarce and rents high in Clinton. ${ }^{68}$ Thirteen years later in 1881, he wrote that he paid sawyers $\$ 2$ to $\$ 2.15$ per day, according to what a man could do. ${ }^{67}$

In 1862 Young sought an engineer-mechanic to run his engines for $\$ 2.50$ per day running time, and $\$ 1.75$ on days of repair work when the mill was not operating. He paid his present man $\$ 2$, but was not satisfied. The new employee would receive $\$ 2.50$ and this would include pay for any over time "for a little late work at night or before starting time in the Morning." ${ }^{\text {" }}$

Young paid laborers $\$ 1$ per day in $1860 ; \$ 1.25$ to $\$ 1.50$ in $1863 ; \$ 2$ in 1865; and $\$ 1.50$ in 1877. Skilled workers such as saw filers fared better. In 1863 Young paid them $\$ 2$ per day; $\$ 2.75$ to $\$ 3.50$ in 1867 ; and $\$ 4$ in 1868 and $1869 .{ }^{69}$ Eight years later in 1877 Young stated that he paid filers $\$ 1.22$ to $\$ 2.75$ for a 10 hour day, but the "time-tickets" for that year show the 
range to be from $\$ 1.40$ to only $\$ 1.60 .{ }^{70}$ This was a year of depression and retrenchment for the company.

In order to maintain stability and prevent migrations of workers among the different mills, the millmen on the river practiced wage comparison and endeavored to pay equal wages for similar types of work. They also cooperated in lowering the wages of their boat crews simultaneously in order to accomplish reduction without stringent opposition.

W. J. Young \& Company informed the Rock Island Lumber \& Manufacturing Company in 1879 that for a 10 hour day they paid car loaders $\$ 1.30$; runners, shovers, trimmers, and tail sawyers $\$ 1.40$; lumber pilers and gang sawyers $\$ 1.50$; edgers $\$ 1.75$ to $\$ 2$; and rotary sawyers $\$ 2.75$ to $\$ 3$. A few common laborers or "old pensioners" received $\$ 1$ to $\$ 1.25$ per day. If they ran more than 10 hours per day, they increased wages by figuring time by the hour. ${ }^{71}$

In 1885 the Musser Lumber Company of Muscatine reported their wages. ${ }^{72}$ Table 7 depicts W. J. Young \& Company wages reported to John P. Weyerhaeuser of Rock Island in 1891. In 1893 the Standard Lumber Company of Dubuque thanked W. J. Young \& Company for responding promptly to a wages inquiry, and enclosed their 1892 list. This firm thanked W. J. Young \& Company for cooperating again in 1894, and maintained that there was a "universal determination" to reduce wages from 10 to 25 per cent, and that they had decided to make a horizontal cut of 10 per cent on all labor under the mill roof. ${ }^{73}$ Also during this depression year, the Rock Island Lumber \& Manufacturing Company wrote:

TABLE 7

\begin{tabular}{|c|c|c|}
\hline \multirow{3}{*}{$\begin{array}{l}\text { Position } \\
\text { Carpenters and Millwrights } \\
\text { Firemen }\end{array}$} & \multicolumn{2}{|c|}{ Cents per Hour } \\
\hline & $20 c$ to & $25 e$ \\
\hline & & $17 \frac{1}{2}$ \\
\hline Watchmen & & 20 \\
\hline $\begin{array}{l}\text { Oilers } \\
\text { Engineers }\end{array}$ & 14 & 18 \\
\hline $\begin{array}{l}\text { Engineers } \\
\text { Gang Sawyers }\end{array}$ & $281 / 2$ & \\
\hline $\begin{array}{l}\text { Gang Sawyers } \\
\text { Band Sawyers }\end{array}$ & $181 / 2$ & \\
\hline $\begin{array}{l}\text { Band Sawyers } \\
\text { Edger Men }\end{array}$ & 25 & 30 \\
\hline $\begin{array}{l}\text { Edger Men } \\
\text { Trimmer Men }\end{array}$ & $21 \frac{1}{2}$ & 24 \\
\hline $\begin{array}{l}\text { Trimmer Men } \\
\text { Filers }\end{array}$ & $171 / 2$ & 20 \\
\hline Filers & $12 \frac{1}{2}$ & $33 \frac{1}{2}$ \\
\hline $\begin{array}{l}\text { Carriage Setters } \\
\text { Log Rollers }\end{array}$ & 20 & \\
\hline $\begin{array}{l}\text { Log Rollers } \\
\text { Shingle Sawyers }\end{array}$ & 15 & \\
\hline Shingle Sawyers & 15 & 20 \\
\hline
\end{tabular}




$\begin{array}{lll}\text { Slab Sawyers } & 14 & 14 \frac{1}{2} \\ \text { Ordinary Labor } & 12 \frac{1}{2} & 14 \\ \text { Foreman in Planing Mill } & 30 & 16 \\ \text { Men in Planing Mill } & 13 \frac{1}{2} & 10 \\ \text { Boys in Planing Mill } & 8 & \\ \text { Head Blacksmith } & 30 & \\ \text { Blacksmith Helpers } & 16 \frac{1}{2} & \\ \text { Foreman in Yard } & 25 & \\ \text { Assistant Foreman in Yard } & 221 \frac{1}{2} & 141 \frac{1}{2} \\ \text { Assorting Green Lumber } & 14 & 15 \\ \text { Assorting Dry Lumber } & 14 \frac{1}{2} & 15 \\ \text { Piling Green Lumber } & 14 & 15 \\ \text { Runners, Green Lumber } & 14 & \\ \text { Car Loading Foreman } & 22 \frac{1}{2} 2 & 15 \\ \text { Car Loading Laborers } & 14 & 27 \\ \text { Teamster with his own Horses } & 26 & \end{array}$

$4 \frac{1}{2}$

6

${ }^{\circ} \mathrm{C}$. H. Young to John P. Weyerhaeuser, Jan. 20, 1891, LPB 170, p. 53.

"Desiring to be in line with other manufacturers regarding wages paid to sawmill employees-we herewith enclose schedules of wages paid by us during the season of 1894." They desired similar information in return, and would keep it confidential. $^{74}$

Foremen, millwrights, exceptional saw filers, blacksmiths, engineers, masons, carpenters, and sawyers drew the best wages. Young paid each man on an individual basis. There was no flat rate for any position, although unskilled workers tended to receive more uniform pay than those in positions that required knowledge and experience to achieve proficiency.

The condition of trade had much to do with wage conditions, and so did labor shortages that occurred during war, harvest, or widespread prosperity. During the Civil War, for example, Young remarked in 1862 that the price of labor had advanced 25 percent. $^{75}$

\section{VIII}

Neither company correspondence nor the Iowa newspapers reveal much about the strikes (at least three) that W. J. Young \& Company experienced. June 1, 1864, L. B. Wadleigh of Young's office explained a delay in shipping: "Our men all struck or we should have got this off before." ${ }^{\prime 6}$ Another strike was for higher wages during the hard year of 1877 when Young curtailed production, the labor force, and wages. The operatives of the Lower Mill appointed a committee of five workmen who presented the firm with a penciled statement in July: 
... The opperatives[sic] asks from the firm an increase in their wages as the present wages is not sufficent[sic] to supply their wants. They ask that $(\$ 1.50)$ one fifty be the lowest wages paid to good hands and that the other men who were cut down will get the wages of last year if it is in the bounds of farity. In complying with this small demand the Company wll have the good will of all the men and [they] will protect the Company's property at all Hazards. ${ }^{77}$

Young, out of town, received the news by telegraph. The last sentence of the workers' statement probably implied a threat to company property; he wired back to George W. Forrest, his head bookkeeper, to keep a force on watch at night; he would return immediately. ${ }^{78}$ Meantime, Forrest announced the company could not increase wages; that they were paying all the firm could afford; otherwise they would gladly pay more. He hoped that the men would rely on their "coolest judgment" and return to work-and apparently they did. ${ }^{79}$

Shortly after the disturbance, a customer complained that a carpenter had to sort and dress pickets that he had received "neither Square, Oblong, or Rounded," but all different: "I think the man who ran the planer while Dressing was either on a Strike, or contemplating one." ${ }^{80}$

In July, 1890, 20 men struck to increase pay from $\$ 1.45$ to $\$ 1.75$. The company refused; the men returned to work. The Northwestern Lumberman and Mississippi Valley Lumberman trade journals commented that sawmill strikes had not been very successful. Besides the Iowa incident, the Northwestern Lumberman cited the failure of the Daniel Shaw Lumber Company employees to obtain a working day of less than 11 hours at Eau Claire. ${ }^{81}$

The Daniel Shaw firm did not inaugurate the 10 hour day until $1893 .^{82}$ W. J. Young \& Company occasionally held its men to 11 and even 12 hours, but usually 10 , not only in the 1890 's, but as early as 1863 . In 1876 the mills started at 6:30 A.M. and quit at 5:30 P.M., allowing 10 hours of work in daylight, and one hour for lunch. ${ }^{83}$

Apparently Young tried to satisfy his workers. Advising another millman, he said that when they worked 11 hours instead of 10, he allowed extra pay, and that he "voluntarily advanced" the pay of his men in 1880 and 1881, averaging a 20 percent raise: 
....We did not think this was any more than right, as there has been a handsome advance in price of lumber that enables us to divide, and then the price of staple articles of food has been quite high . . . Our men are well pleased, and we want it to be so. We hope you will be able to compromise with your men, and make them feel that you are their friend. ${ }^{84}$

Hotchkiss states that Young took a "fatherly interest" in his "army of employees" and, "When there was no work for all, he made work, that no deserving employee should suffer from poverty." ${ }^{85}$ The editor of the Clinton Age, writing in the depression years of 1877 and 1894, maintained that the city's millmen operated their mills solely to give work to employees, and noted that the lumbermen had to pay higher insurance rates on excessive amounts of piled lumber. In September, 1894, after the mills did close, and 1,000 men were out of work, the editor remarked that the lumber manufacturers deserved the highest credit for furnishing employment as long as possible: "They certainly have exhibited an immense amount of grit and nerve to go on piling up lumber when the demand was so limited." ${ }^{86}$

Appreciative letters from individual employees indicate that Young was benevolent in specific instances. Young himself might mention the welfare of his men at stake should a log shortage force curtailment of sawing. ${ }^{87}$ Possibly Young did feel a personal responsibility for his workers' welfare. In addition, of course, if factors forced workmen to leave Clinton to seek employment elsewhere, millmen could have trouble reassembling full crews of qualified men.

With his "hearty approval," Young's men organized their own accident insurance. In 1871 employees held a supper and dance, and heard a report of the "Old Mill Protective Association," which had existed for eight months. Each member paid $\$ .50$ a month to provide a fund for the relief of persons who met with accidents that prevented them from working. The Association paid $\$ 2$ per day for the first month off work, $\$ 1.50$ the second, and $\$ 1$ per day for the third month, after which no member had any further claim. A committee of three handled all claims. During the eight months in operation, $50 \mathrm{mem}-$ bers had paid $\$ 200$ into the treasury, and seven had received aid aggregating $\$ 165$. The reporting secretary closed with an earnest appeal for the workers to "cultivate the social" in their 
nature, and thus "dignify labor." 88

In 1895 the employees of neighbor C. Lamb \& Sons organized a "mutual accident insurance company," with 85 members and no fees. Each member would pay those injured $\$ .10$ per week for a month. The purpose of the organization was to avoid the expensive insurance that regular companies offered to sawmill employees. ${ }^{89}$

\section{IX}

How paternalistic was the attitude and influence of W. J. Young as regards his employees? Someone interested in starting a grocery store in Clinton inquired whether Young maintained a company store, or influenced trade in the community. Young replied:

We pay our men cash, and they trade where they please.

We never try to influence trade in any case, as it would not be right. Both men and grocers would be disposed to find fault..$^{90}$

There is evidence that Young tried to influence the vote of his workers, and everybody in town, on certain issues. In 1884 some vitriolic, anonymous farmers claimed that they knew that Young tried to influence his "Workmans" to vote Republican, and threatened him with a "loss of thousands of Dollars," presumably by fire, if he did not desist. ${ }^{91}$

In 1882 the citizens of Clinton voted in favor of a prohibition amendment. The next day Young received an inquiry "in justice to yourself \& for my own curiosity," whether he had proposed to shut down on election day, but pay the men anyway, and try to persuade them to vote for prohibition. The inquirer also heard that Young had threatened to discharge men who failed to vote as he wished, and that he had stationed observers at the polls. Finally, did Young allow a premium for each employee who abstained from the use of liquor? A man in Young's office answered:

...no undue influences whatever, either directly or indirectly, were brought to bear on our employees on the 27th of June to cause them to vote in any other way than they thought best to vote. We, as well as many of our men were strongly in favor of the adoption of the Amendment and worked to accomplish that end before and on election day - but our men were free to vote just as they pleased.

Mr. Ewing also explained that the company had a rule that they enforced: "No man shall continue in our service, who is an habitual drinker or who frequents places where intoxi- 
cants are sold." 92

Before the election, Young wrote to a customer, "So my dear friend you must distinctly understand that we are Personal Liberty Loving Fellows but will vote for the amendment if we live till 27th." ${ }^{\text {93 }}$ After the election Young wrote, "Thank God," that there was a majority of 90 for the amendment. ${ }^{94} \mathrm{An}$ anonymous citizen of Lyons wrote to Young, "How dare you take prominent part in prohibition with so much property at stake? Be Careful! Be Careful! Go slow!" ${ }^{95}$

That Young was an ardent prohibitionist is apparent in his words of November 20, 1880:

Hurrah for the Right Mr. \& Mrs. Hays. [sic] We have reason to thank God for the example they have set at the White House. I do hope that Mr. \& Mrs. Garfield will follow their example, and that no intoxicating beverage may be found on their table. ${ }^{96}$

Young's numerous letters answering requests for employment usually stressed temperance. The issue involved safety: "I am glad to hear that you do not taste anything that intoxicates. I don't [sic] want any man that is helping me to risk his life by even going inside a drinking saloon." ${ }^{\text {97 }}$ While Young believed that drinking caused moral and physical ruin, intoxicated workers also risked death from sawmill machinery. Young distributed temperance newspapers among the men in the mills, in his logging camps, and on his tow boats. ${ }^{98}$ One of his laborers, a sympathizer for the cause, wrote anonymously in 1886:

Feel it is my duty to give you notice that the Saloon keepers of this City [have] two men employed in the Temperance Society on salary. They know all about what is going on in the same. ${ }^{99}$

The people of Clinton were well aware of the influence of the millowners in the city. Much of the population depended upon the mills for a living. Those who worked for Young felt his restraining hand in their personal lives. They could not afford to let him see them entering a tavern. One day a week, however, they could be sure of not being under his surveillance-at least in the mills. That day was Sunday. Young was an extremely devout pillar of the Methodist Episcopal Church. In keeping with this, he said, “. . .nothing but the necessity of saving life or property will induce us to work on Sunday."100 


\section{NOTES}

${ }^{1}$ Martin Deming Lewis, Lumberman from Flint: The Michigan Career of Henry H. Crapo, 1855-1869 (Detroit: Wayne State University Press, 1958), 255.

${ }^{2}$ George Bernhardt Hartman, "The Iowa Sawmill Industry," Iowa Journal of History and Politics (v. 40, No. 1, Jan., 1942), 87.

${ }^{3}$ Floyd B. Haworth, The Economic Development of the Woodworking Industry in Iowa (Iowa Studies in Business XIII; Iowa City: College of Commerce, State University of Iowa, 1933), 36, 88.

${ }^{4}$ Lydia C. Belthuis, "The Lumber Industry in Eastern Iowa," Iowa Journal of History and Politics (v. 46, No. 2, Apr., 1948), 144.

${ }^{5}$ Clinton Age, Feb. 11, 1870.

${ }^{6}$ Ibid., Jan. 27, 1871.

${ }^{7}$ Ibid. Young never published his expenses for years after 1869.

${ }^{8}$ Ibid., Jan. 27, and Mar. 24, 1871.

${ }^{9}$ Ibid., Apr. 28, 1893 (excerpts from earlier years ); Feb. 11, 1870; Jan. 27, 1871; Jan. 7, 1874; Mar. 19, 1875; Dec. 24, 1875; and Jan. 2,1877 .

${ }^{10}$ Ibid., Jan. 12, 1877.

${ }^{11}$ Agnes M. Larson, History of the White Pine Industry in Minnesota (Minneapolis: University of Minnesota Press, 1949), 105.

${ }^{12}$ Belthuis, "Lumber Industry in Eastern Iowa," 137.

${ }^{13}$ Haworth, Woodworking Industry in Iowa, 33, 36, 88.

${ }^{14}$ Belthuis, "Lumber Industry in Eastern Iowa," 144.

${ }^{15}$ Haworth, Woodworking Industry in Iowa," 143.

${ }^{16}$ Belthuis, "Lumber Industry in Eastern Iowa," 143.

${ }^{17}$ George W. Hotchkiss, History of the Lumber and Forest Industry of the Northwest (Chicago: George W. Hotchkiss \& Co., 1898), $587-88,599$.

${ }^{18}$ Clinton Age, Feb. 11 and 18, 1870.

${ }^{19} \mathrm{Ibd}$., Dec. 8, 1871; Mar. 8, Feb. 23, and Aug. 23, 1872; May 2 and 23, 1873; May 1, and Aug. 7, 1874; June 11, 1875; and Jan. 12, 1877.

${ }^{20}$ Ibid., Feb. 18, 1870.

${ }^{21}$ Ibid., May 25, 1877.

${ }^{22}$ Hotchkiss, Lumber and Forest History, 588.

${ }^{23}$ Clinton Age, Mar. 29, 1872. 12,1877 .

${ }^{24}$ Hotchkiss, Lumber and Forest Industry, 587-99. Clinton Age, Jan.

${ }^{25}$ Northwestern Lumberman, May 27, 1893, 10.

${ }^{26}$ W. J. Young to R. G. Brown, De Witt, Ia., Jan. 7, 1867, LBP 11, 615. Note: Unless otherwise stated, manuscript sources are from the W. J. Young \& Co. special collection at the University of Iowa, and Young wrote his correspondence at Clinton. The notes designate the particular record, letter-press-book (LPB), or box where information is found.

${ }^{27}$ Northwestern Lumberman, July 26, 1890, 3.

${ }^{28}$ Ralph W. Hidy, Frank Ernest Hill, and Allan Nevins, Timber and Men: The Weyerhaeuser Story (New York: The Macmillan Company, 1963), 36-37.

${ }^{29}$ Clnton Age, Jan. 13, 1871.

${ }^{30}$ Ibid., Apr. 17, 1874.

${ }^{31}$ Ibid., Apr. 1, 1870.

${ }^{32}$ Northwestern Lumberman, June 13, 1896, 13. 
${ }^{33}$ Clinton Age, Dec, 15, 1871.

${ }^{34}$ Ibid., Jan. 13, 1893.

${ }^{35}$ Ibid., Jan. 12, 1898.

${ }^{36}$ Ibid., Jan. 12, 1877; Jan. 13, and July 21, 1893.

${ }^{37}$ Ibid., Mar. 23, 1877.

${ }^{38}$ L. C. Eastman, Clinton, Ia., to W. J. Young, Dec. 9, 1892.

${ }^{39}$ Hotchkiss, Lumber and Forest Industry, 589-90. Northwestern Lumberman, Sept. 22, 1894, 3. Clinton Age, June 9, 1896; June 26, 1890; May 27, 1893.

${ }^{40}$ U. S. Department of Interior, A Compendium of the Ninth Census, June 1, 1870 (Washington: Government Printing Office, 1882), 180. ${ }^{41}$ Clinton Age, Nov. 4, 1870.

${ }^{42}$ Pay Roll Records, Aug., 1870.

${ }^{43}$ Census of Iowa as Returned in the Year 1875 (Des Moines: Iowa Executive Council, 1875), 16-17.

${ }^{44}$ Clinton Age, Jan. 12, 1876.

${ }^{45}$ Pay Roll Records, Aug. 1876.

${ }^{46}$ U. S. Department of Interior, Statistics of the Population of the United States, Tenth Census, June 1, 1880 (Washington: Government Printing Office, 1883), p. 162. Pay Roll Records, Aug., 1881.

${ }^{47}$ U. S. Department of Interior, Compendium of the Eleventh Census, 1890, Part I, Population (Washington, Government Printing Office, 1892), 146. Pay Roll Records, Aug., 1890.

${ }^{48}$ Census of Iowa as Reported for the Year 1895 (Des Moines: Iowa Executive Council, 1896), 250-52. Pay Roll Records, Aug. 1895.

- AS1,e

${ }^{49}$ Pay Roll Records, 1863-1901. The 1863 figure in Table 3 is for September, the first month in the earliest ledger extant.

${ }^{50}$ George B. Engberg, "Lumber and Labor in the Lake States," Minnesota History (v. 36, No. 5, Mar., 1959), 153.

${ }^{51}$ U. S. Department of Interior, The Statistics of the Papulation of the United States, June 1, 1870, Ninth Census, Vol. 1 (Washington: Government Printing Office, 1872), 733. U. S. Department of Interior, The Statistics of the Population of the United States at the Tenth Census, June 1, 1880 (Washington: Government Printing Office, 1883), 507, 822. Census of Iowa for the Year 1885 (Des Moines: Iowa Executive Council, 1885), 18-19.

${ }^{52}$ Hartman, "Iowa Sawmill Industry," 79.

${ }^{53}$ Engberg, "Lumber and Labor," 154.

${ }^{54}$ W. J. Young to Z. H. Lucky, Sterling, Ill., July 22, 1863, LPB 4, 442.

${ }^{55}$ Engberg, "Lumber and Labor," 155.

${ }^{56}$ W. J. Young to G. C. Hixon, La Crosse, Wis., July 25, 1868, General Letter Book, Apr. 9 - Aug. 19, 1868, 743.

${ }^{57}$ W. J. Young to Messrs. Bodfish \& Co., Iuka, Ia., Nov. 13, 1863, LPB 5, 61 .

${ }^{58}$ Calculated from figures in the Record Book, Box 173.

${ }^{59}$ Ibid.

${ }^{60}$ W. J. Young to C. H. Young, n.p., July 3, 1893, Box 174.

${ }^{61}$ W. J. Young to L. L. Rogers, Wheatland, Ia., May 28, 1860, LPB 1, p. 397. 

$2,57-60$

${ }^{62}$ W. J. Young to F. McBurnie, Cincinnati, Ohio, July 6, 1860, LPB

${ }^{63}$ W. J. Young to Loomis \& Ludington, Chicago, Ill., Oct. 26, 1860, LPB 2, 173

${ }^{64}$ W. J. Young to D. Donaldson, Rock Island, Ill., Apr. 6, 1881, LPB 2,381 .

${ }^{65}$ W. J. Young to James J. Brooks, Mt. Vernon, Ia., Feb. 27, 1865, LPB 6, 660. To French \& Davis, Davenport, Ia., July 20, 1865, LPB 7, 685.

${ }^{66}$ W. J. Young to H. A. Dolson, Bellview, Ia., Mar. 3, 1868, General Letter Book, Oct. 7, 1867 - Mar. 19, 1868, 749. $57,346$.

${ }^{67}$ W. J. Young to Y. H. Knowles, Decatur, Ia., Mar, 20, 1881, LPB

${ }^{68}$ W. J. Young to W. N. Howard, Onalaska, Wis., May 25, 1862, LPB 3, 25.

${ }^{60}$ W. J. Young to F. McBurnie, Cincinnati, Ohio, July 6, 1860, LPB 2, 57-60; to M. L. Rogers, Wheatland, Ia., Nov. 10, 1863, LPB 5, 54; to French \& Davis, Davenport, Ia., July 20, 1865, LPB 7, 685; to J. A. Hicks, Wheatland, Ia., Aug. 9, 1866, LPB 10, 703; to J. W. Dwight, Washington, D. C., Jan. 10, 1878, LPB 53, 744; to William Lentz, Fort Madison, Ia., Oct. 16, 1863, LPB 4, 695; to A. J. Scott, Muskegon, Mich., July 1, 1867, LPB 12, 378; to Atwood P. Jones, Minneapolis, Minn., Aug. 27, 1867, LPB 12, 670; to John Shippy Sandy Hill, N. Y., Dec. 23, 1869, LPB 16, 894.

${ }^{70}$ W. J. Young to N. C. Burrows, Mt. Vernon, Ia., Mar. 13, 1877, LPB 50, 557.

${ }^{71}$ W. F. Battis, Clinton, Ia., to Rock Island Lumber \& Manufacturing Co., Rock Island, Ill., July 18, 1879, LPB 58, 408.

${ }^{72}$ Musser Lumber Co., Muscatine, Ia., to W. J. Young \& Co. Feb. 17,1885 , Box 54 .

${ }^{73}$ Standard Lumber Co., Dubuque, Ia., to W. J. Young \& Co., Apr. 6, 1894, Box 173.

${ }^{74}$ Rock Island Lumber \& Manufacturing Co., Rock Island, Ill., to W. J. Young \& Co., Nov. 23, 1894, Box 173.

${ }^{75}$ W. J. Young to H. C. Henderson, Marshalltown, Ia., Aug. 18, 1862, LPB 3, 147. 5,332 .

${ }^{76}$ L. B. Wadleigh to O. B. Dutton, Norway, Ia., June 1, 1864, LPB

${ }^{77}$ Committee on Strike to W. J. Young \& Co., July 25, 1877, Box 173.

${ }^{78}$ W. J. Young, Wabasha, Minn., to George W. Forrest, Clinton, Ia., July 25, 1877, Box 173. To Forrest from La Crosse, Wis., July 26, 1877, Box 173 .

${ }^{79}$ George W. Forrest, Clinton, Ia. to Committee on Strike, July 25, 1877, LPB 52, 244. Box 173

${ }^{80}$ D. Whitney, De Witt, Ia., to W. J. Young \& Co., July 28, 1877,

${ }^{81}$ Northwestern Lumberman, July 26, 1890, 9. A. R. Reynolds discusses the workers' struggle for the 10 hour day in The Daniel Shaw Lumber Company: A Case Study of the Wisconsin Lumbering Frontier (Business History Series: Graduate School of Business Administration, edited by Ralph H. Hidy; New York: New York University Press, 1957), 90-92. 
${ }^{82}$ Ibid., 92.

${ }^{83}$ W. J. Young to J. W. Dwight, Washington, D. C., Jan. 10, 1878, LPB 53, 744 (mentions 1863, 1865, and 1867); to N. C. Burrows, Mt. Vernon, Ia., Mar. 13, 1877, LPB 50, 557; to P. E. Hall, Cedar Rapids, Ia., Sept. 24, 1879, LPB 59, 395; to C. C. Wheeler, Chicago, Ill., June 16, 1881, LPB 70, 65; to Eugene Shaw, Chicago, Ill., July 22, 1881, LPB 71, 275. W. F. Battis, Clinton, Ia., to Rock Island Lumber \& Manufacturing Co., Rock Island, Ill., July 18, 1879, LPB 58, 408. Clinton Age, Oct. 13, 1876.

${ }^{84}$ W. J. Young to Eugene Shaw, Chicago, Ill., July 22, 1881, LPB 71,275 .

${ }^{85}$ Hotchkiss, Lumber and Forest History, 590.

${ }^{86}$ Clinton Age, Jan. 12, 1877; Aug. 10, and Sept. 21, 1894.

${ }^{87}$ W. J. Young to Thomas Irvine, Beef Slough, Wis., Sept. 19, 1882, LPB 57, 753.

${ }^{88}$ Clinton Age, Dec. 8, 1871.

${ }^{89}$ Clinton Weekly Age, Aug. 9, 1895.

${ }^{90}$ W. J. Young to R. W. Weymouth, Manister, Mich., Sept. 5, 1871, LPB 52, 592.

${ }^{91}$ Anonymous letter to W. I. Young, 1884, Box 42.

${ }^{92}$ A. G. Ewing, Clinton, Ia., to E. B. Bradley, Wellan, Pa., June 30, 1882, LPB 80, 575.

${ }^{93}$ W. J. Young to P. E. Hall, General Manager, Sioux City \& Pacific Railways, June 24, 1882, LPB 80, 493. 80,543 .

${ }^{94}$ W. J. Young to J. C. Pickler, Muscatine, Ia., June 28, 1882, LPB

95“A Citizen," Lyons, Ia., to W. J. Young, Aug. 12, 1884, Box 42.

${ }^{96}$ W. J. Young to Captain Samuel Van Sant, Davenport, Ia., Nov. 20, 1880, LPB 57, 283.

${ }_{97}$ W. J. Young to William Desmond, Galena, Ill., Feb. 23, 1882, LPB 57, 592.

${ }^{98}$ W. J. Young to E. W. Brady, Proprietor and publisher of the Northwestern News, Davenport, Ia., Jan. 22 and 25, 1883, LPB 57, 823, 829. E. W. Brady, Davenport, Ia., to W. J. Young, May 20, 1885, Box 53.

${ }^{99}$ “'One of your Laborers," to W. J. Young, June 29, 1886, Box 91-A. ${ }^{100}$ W. J. Young to David Fraser, Eagle Works, Chicago, Ill., July 5, 1869, LPB 18, 379.

\section{FROM THE EDITOR'S DESK}

The Chicago Historical Society has recently published The Great Chicago Fire, Paul M. Angle, editor, 128 pages, fifty-nine full-page illustrations, $\$ 7.50$. This book is a very interesting and informative analysis of that historic event which almost totally destroyed one of our great mid-western cities in the 1870 's. The reader will be particularly interested in the 
Copyright of Annals of Iowa is the property of State of Iowa, by \& through the State Historical Society of Iowa and its content may not be copied or emailed to multiple sites or posted to a listserv without the copyright holder's express written permission. However, users may print, download, or email articles for individual use. 